\title{
Perbincangan Sosialisasi Kebijakan Pendidikan Islam
}

\author{
Dian $\mathrm{N}$ amora \\ Univarsitas I slam N egeri Sultan Syarif Kasim Riau, Indonesia \\ diannamora762@gmail.com
}

\author{
Abu Bakar \\ Universitas I slam N egeri Sultan Syarif Kasim Riau, Indonesia \\ abu.bakar@uin-suska.ac.id.com
}

\begin{abstract}
Abstrak
The purpose of writing this article is to examine the approach to the formulation of education policy problems, the stages of policy formulation and the formulation of education policies, actors in the formulation of education policies and must be able to socialize education policies and education policy socialization strategies through the socialization media of education policy. This method of writing uses the methodology of the study of literature. The writing of this article is done by reviewing several journals related to education policy contained in the google scholar data base. The results of the study are then spelled out through scientific articles. To complete the Discussion of Socialization of Islamic Education Policy, education organizers must be able to know the framework of education policy development. Namely by contributing and approaching the formulation of education policy problems, the stage of formulation of policy problems and the formulation of education policies, actors in the formulation of education policies and must be able to do the stage of socialization of education policy at the preparatory stage, the stage of mimicking (play stage), and the stage of action (game stage), and able to conduct educational policy socialization strategies through the medium of socialization of policy. education.
\end{abstract}

Keywords: Discussion of Socialization; Education Policy; Islamic Education 


\begin{abstract}
Abstrak
Tujuan penulisan artikel ini adalah untuk mengkaji pendekatan terhadap perumusan masalah kebijakan pendidikan, tahapan perumusan masalah kebijakan dan perumusan kebijakan pendidikan, aktor dalam perumusan kebijakan pendidikan serta harus mampu melakukan sosialisasi kebijakan pendidikan dan strategi sosialisasi kebijakan pendidikan melalui media sosialisasai kebijakan pendidikan. M etode penulisan ini menggunakan metodologi studi kepustakan. Penulisan artikel ini dilakukan dengan mengkaji beberapa journal yang berhubungan dengan kebijakan pendidikan yang terdapat pada data base google scholar. Hasil dari pengkajian kemudian dijabarkan melalui artikel ilmiah. Untuk menyelesaikan Perbincangan Sosialisasi Kebijakan Pendidikan Islam maka penyelenggara pendidikan harus mampu mengetahui kerangka kerja pengembangan kebijakan pendidikan. Yaitu dengan mengkontribusikan dan melakukan pendekatan terhadap perumusan masalah kebijakan pendidikan, tahapan perumusan masalah kebijakan dan perumusan kebijakan pendidikan, aktor dalam perumusan kebijakan pendidikan serta harus mampu melakukan tahapan sosialisasi kebijakan pendidikan pada tahap persiapan (preparatory stage), tahap meniru (play stage), dan tahap tindakan (game stage), serta mampu melakukan strategi sosialisasi kebijakan pendidikan melalui media sosialisasai kebijakan pendidikan.
\end{abstract}

Kata kunci: Persoalan Sosialisasi, Kebijakan Pendidikan; Pendidikan Islam

\title{
A. Pendahuluan
}

T ujuan sosialisasi kebijakan pendidikan pada umum adalah mengupayakan masyarakat luas memahami dan mampu menginternalisasikan makna dari tujuan dan konsep dari keputusan pemerintah, masyarakat umum mengetahui dan memahami perkembangan implementasi kebijakan dan progam pemerintah sebagai bagian dari pertanggungjawaban terhadap masyarakat, menjadi bagian dari kegiatan-kegiatan pelibatan masyarakat yang terdapat dalam siklus progam dari kebijaksanaan pemerintah. Sedangkan secara khusus adalah agar terdapatnya kerjasama dan komitmen antara pemerintah dengan masyarakat, atau antara masyarakat dengan masyarakat untuk membua terencana, menjalankan rencana dan memonitor-mensupervisi secara bersama, dapat membangkitkan motivasi kelompok strategis dan kelompok peduli untuk melakukan tindakan baik dalam kerjasama maupun membangun pengawasan terhadap tujuan kebijakan pendidikan, dan menyebarluaskan hasil-hasil 
perkembangan program kebijakan di bidang pembanguan pendidikan kepada masyarakat luas. ( D r. Arwildayanto et al., 2018)

Biasanya berbagai permasalahan seputar sosialisasi kebijakan, belum diketahuinya aturan, prosedur, tanggungjawab, batasan, koordinasi, tindakan yang tepat belum diketahui masyarakat. U ntuk mengatasi agar tidak terjadi miskommunikasi, kesalahan intepretasi, pada hakekatnya sosialisasi kebijakan ini harus dilakukan dalam konteks organisasi yang menyeluruh dengan tujuan dan target yang jelas, prioritas yang jelas sumber daya pendukung yang jelas pula. Sosialisasi kebijakan pendidikan menjadi sebuah mekanisme penyampaian informasi kebijakan pendidikan kepada publik. Sosialisasi ini dapat dilakukan dengan berbagai media, baik cetak maupun elektronik. Sedangkan kebijakan merupakan aturan tertulis yang merupakan keputusan formal organisasi yang bersifat mengikat, yang mengatur perilaku dengan tujuan untuk menciptakan tata nilai baru dalam masyarakat.

Yang menjadi Masalah dalam formulasi kebijakan pendidikan terletak pada Perumusan kebijakan pendidikan yang merupakan tahapan kedua dalam siklus kebijakan pendidikan. Sebagai tahapan kedua, formulasi kebijakan dengan sendirinya tidak dapat dilepaskan dari tahapan agenda setting. Secara fundamental tahapan ini terjadi tatkala pemerintah mengakui keberdaan masalah-masalah publik dan menyadari adanya kebutuhan dan tuntunan untuk melakukan sesuatu dalam rangka mengatasi masalah tersebut. M eskipun sebuah kebijakan telah disahkan, bukan berarti rumusan kebijkan telah bebas dari berbagai permasalah. Banyak problem yang muncul disekitar rumusan atau statemennya yang kurang atau tidak jelas. Problematika tersebut bersumber dari beberapa hal berikut ini: 1) pembuat kebijakan pendidikan kurang menguasai pengetahuan, informasi, keterangan persoalanpersoalan pendidikan baik yang bersifat konseptual maupun substansial. 2) sumber acuan para pembuat kebajikan pendidikan, baik formal maupun tidak formal formal berbeda-beda, oleh karena itu sikap kompromi atau jalan tengah sering diambil sebagai alternatif untuk mengakomodasikannya. Kenyataan ini yang membuat rumusan kebijakan pendidikan yang sering mengambang dan tidak fokus. 3) terlalu banyak maupun kurangnya informasi bisa berakibat tidak jelasnya statemen kebijakan pendidikan. hal ini dikarenakan kurangnya informasi menyebabkan perbincangan dan alternatif-alternatif yang dipilih menjadi terlalu sederhana. Sedangkan banyaknya informasi menyebabkan para perumus kebijakan pendidikan dihadapkan pada kesulitan ketika bermaksud mensintesakan persoalan dan alternatif yang akan dipilih.

Untuk menyelesaikan Perbincangan Sosialisasi Kebijakan Pendidikan Islam maka penyelenggara pendidikan harus mampu mengetahui hakikat kebijakan pendidikan terutama 
yang berhubungan dengan kerangka kerja pengembangan kebijakan pendidikan. O leh sebab itu tujuan penulisan artikel ini adalah untuk mengkaji persoalan sosialisasi kebijakan pendidikan islam melalui pendekatan terhadap perumusan masalah kebijakan pendidikan, tahapan perumusan masalah kebijakan dan perumusan kebijakan pendidikan, aktor dalam perumusan kebijakan pendidikan serta harus mampu melakukan sosialisasi kebijakan pendidikan dan strategi sosialisasi kebijakan pendidikan melalui media sosialisasai kebijakan pendidikan. Metode penulisan ini menggunakan metodologi studi kepustakan. Penulisan artikel ini dilakukan dengan mengkaji beberapa journal yang berhubungan dengan kebijakan pendidikan yang terdapat pada data base google scholar. Hasil dari pengkajian kemudian dijabarkan melalui artikel ilmiah.

\section{B. Pembahasan}

\section{Sosialisasi Kebijakan Pendidikan}

Sosialisasi merupakan sebuah proses yang paling penting yang secara sadar atau tidak kita sudah jalani dalam kesehariannya. Sosialisasi adalah penyampaian informasi secara terbuka berupa (peraturan, progam, keputusan) dari satu pihak (pemilik progam) ke pihak lain (masyarakat luas) dan proses pemberdayaan, dimana diharapkan dapat menumbuhkan perubahan sikap, perilaku masyarakat dan menumbuhkan kesadaran kritis.(Perkotaan, 2009)

Sosialisasi kebijakan dilakukan, untuk proses pengenalan nila-nilai yang terkandung dalam kebijakan itu, prosedur, maupun kesamaan pemahaman yang sedemikian rupa penting dilakukan hingga akhirnya terbentuk suatu kesatuan penafsiran antar individu di dalam organisasi tersebut. M aka dapat dikatakan seorang individu tidak pernah mengikuti sosialisasi dengan sempurna, maka ia dapat diumpamakan sebagai manusia belum utuh menjalankan kebijakan.

Sosialisasi kebijakan pendidikan menjadi sebuah mekanisme penyampaian informasi kebijakan pendidikan kepada publik. Sosialisasi ini dapat dilakukan dengan berbagai media,baik cetak maupun elektronik. Sedangkan kebijakan merupakan aturan tertulis yang merupakan keputusan formal organisasi yang bersifat mengikat, yang mengatur perilaku dengan tujuan untuk menciptakan tata nilai baru dalam masyarakat.

Jadi dalam konteks kebijakan, menurut H arton dan H unt (1989-1989) sosialisasi pada prinsipnya adalah sistem agar Sosialisasi Kebijakan Pendidikan suatu keputusan dapat mencapai tujuannya suatu keputusan dapat mencapai tujuannya. Suatu program kebijakan disosialisasikan agar mempunyai tujuan atau efek yang di inginkan. sosialisasi di pandang 
sebagai proses interaksi antara satu perangkat pelaksana, tindakan dan tujuan yang dapat mencapai sasaran kebijakan, dimana di dalam sosialisasi kebijakan aktor, organisasi, prosedur, dan teknik di pakai secara bersama.

Sosialisasi kebijakan pendidikan merupakan suatu mekanisme penyampaian informasi suatu sikap dan tindakan yang diambil oleh aktor atau dengan kemufakatan group pembuat kebijakan sebagai upaya dalam menyelesaikan satu persoalan atau suatu masalah dalam bidang pendidikan.

\section{Perbincangan Sosialisasi Kebijakan Pendidikan Islam}

Kebijakan pendidikan merupakan hasil akhir dari sebuah keputusan dibidang pendidikan yang diambil dengan memperhatikan komponen-komponen pendidikan dan komponen sosial yang berkaitan.(Solichin, 2015) Kebijakan pendidikan yang dilahirkan harus bersifat intredisipliner dan kontekstual, Untuk dapat melahirkan kebijakan pendidikan maka diperlukan analisis kebijakan pendidikan yang tepat. Analisis kebijakan pendidikan merupakan cara untuk memecahkan persoalan yang berhubungan dengan pendidikan melalui pendeiatan ilmu sosial terapan dengan menggunakan metode inquiri dan argumen ganda. ( 0 ktavia et al., 2021)

Contoh kasus pada komunikasi kebijakan pendidikan yaitu mengenai kebijakan pembebasan biaya sekolah negeri Jembrana, tidak ditemukan kebijakan dalam bentuk peraturan legal-formal untuk dijadikan aebagai dasar hukum yang bersifat formal. Khususnya bagi pelaksanaan kebijakannya. Dikemukakan oleh responden, bahwa proses kebijakannya adalah adanya "instruksi-instruksi" kepada kepala dinas, dan terus ke jenjang administrasi kebawahnya, hingga ke tingkat sekolah, dan disampaikan secara langsung kepada masyarakat. Prinsipnya sejak tahun 2021, bupati memerintahkan agar setiap sekolah negeri di jembrana tidak boleh memungut biaya pendidikan dari siswa. Pada saat itu, kebijakan ini tidak mendapatkan tanggapan yang memadai DPRD. Kebijakan langsung dijalankan, dan diawasi secara ketat. Dilaporkan oleh informan penelitian, pada tahun 2021, dapat dikatakan setiap hari bupati melakukan kunjungan ke sekolah-sekolah negeri secara bergiliran. Disela waktu, bupati mengunjungi sekolah swasta.

Selama tahun 2001-2002, kebijakan tersebut berjalan. Selama itu kebijakan tersebut tidak ditentang. Bahkan ketiadaan kebijakan formal sebagai payung hukum, tidak menjadi isu politik bagi DPRD saat itu. Setelah dua tahun berturut-turut kebijakan tersebut tidak ditentang, bupati mengeluarkan keputusan bupati nomor 24 tahun 2003 tentang pembebasan iuran wajib pada SD, SLTP, SM U, dan SM K N egeri di kabupaten Jembrana, yang ditanda- 
tangani pada 22 Januari 2003. Selanjutnya tahun 2006 diterbitkan perda no. 10/ 2006 tentang subsidi biaya pendidikan pada TK, SD, SM P, SM A, dan SM K N egeri di kabupaten Jembrana. ( T ilaar, H.A.R. dan N ugroho, 2016)

Kemudian perbincangan sosialisasi yang rentan terjadi adalah kebijakan pada M ateri pelajaran yang terakomodasi dalam kurikulum menggambarkan standar kemampuan dasar yang wajib dimiliki peserta didik pada masing-masing jenjang pendidikan Pemerintah telah berupaya keras untuk menanggulangi berbagai permasalahan yang muncul dalam dunia pendidikan di Indonesia, termasuk kurikulum. U paya yang dapat dirasakan yaitu adanya pemerataan kesempatan pendidikan di semua jenjang. Bahkan pemerintah telah mengundangkan UUSPN N o. 20 tahun 2003 dan PP N 0. 19 tahun 2005 tentang Standar $\mathrm{N}$ asional Pendidikan, dan kebijakan pemerintah tidak menyusun kurikulum pendidikan secara nasional dan lebih menyerahkan penyusunannya di tingkat satuan pendidikan merupakan perwujudan dari reformasi pendidikan, untuk mewujudkan tiga strategi pembaharuan, yaitu: (a) pengembangan pelaksanaan kurikulum berbasis kompetensi, (b) pelaksanaan otonomi manajemen pendidikan, (c) pemberdayaan peran serta masyarakat.(Rohman, 2015)

Meskipun demikian, sejauh ini, upaya tersebut belum dapat dirasakan hasilnya secara penuh jika dilihat dari kualitas kurikulum pendidikan yang dimiliki sampai saat ini. Pendidikan yang selama ini dijalankan hanya berupa "pelatihan", bukan mengembangkan peserta didik menjadi pribadi mandiri, hasilnya orang-orang menjadi terampil tetapi berkepribadian nol. Sasaran akhir pendidikan, pada hakikatnya adalah membekali peserta didik dengan pengetahuan, ketrampilan, sikap, kepribadian, dan nilai-nilai yang akan membuat mereka hidup mandiri dan fungsional di masyarakat.

Dalam pandangan dunia pendidikan, keberhasilan program pendidikan sangat bergantung pada perencanaan program kurikulum, karena kurikulum pada dasarnya berfungsi untuk menyediakan program pendidikan yang relevan bagi pencapaian sasaran akhir pendidikan. Dengan kata lain fungsi kurikulum adalah "shaping the individual selver, i.e determining what men become". Untuk mencapai itu kurikulum berfungsi menyiapkan dan membentuk peserta didik agar dapat menjadi manusia dan sasaran akhir program pendidikan. Program kurikulum harus diorientasikan dan disesuaikan dengan kebutuhan masa kini dan masa yang akan datang.

Begitu banyak perbincangan-perbincangan pembuatan kebijakan tidak terlepas hari hal yang bersifat politis dikarenakan dalam pembuatan kebijakan akan terjadi proses pertentangan antar kelompok yang mempunyai kepentingan yang berbeda-beda. M aka dalam 
pengembangan kebijakan pendidikan tersebut harus mampu mengalahkan ego pribadi dan kelompok sehingga pertentangan yang terjadi bersigat netral dan objektif. O leh sebab itu para pembuat kebijakan pendidikan harus mampu mengadakan pendekatan terhadap perumusan masalah kebijakan pendidikan, tahapan perumusan masalah kebijakan dan perumusan kebijakan pendidikan, aktor dalam perumusan kebijakan pendidikan serta harus mampu melakukan sosialisasi kebijakan pendidikan dan strategi sosialisasi kebijakan pendidikan melalui media sosialisasai kebijakan pendidikan.

\section{Pendekatan T erhadap Perumusan M asalah Kebijakan Pendidikan}

Ada dua pendekatan yang biasa digunakan antara lain pendekatan fungsionalisme dan pendekatan empirisme. Pendekatan Fungsionalisme dipelopori Burton Clark, menekankan pada pemeliharaan sumber daya manusia ( preservation of human resources). M isalnya dalam konteks pemerataan dan peningkatan mutu pendidikan dengan kebijakan wajib belajar 12 tahun, diperlukan perubahan teknologi dan pengembangan sistem pendidikan. Termasuk pemilihan program pendidikan yang relevan agar upaya perluasan pendidikan lebih merata dalam konteks interaksi antara lembaga pendidikan dengan lembaga-lembaga lainnya dalam masyarakat termasuk perkembangan teknologi yang terjadi dengan cepat. (M uhibbin, 2016)

Sementara itu pendekatan empirisme memberikan penekanan pada perlunya diagnosis terhadap masalah pemerataan pendidikan dengan cara mengkombinasikan antara metodologi dan substansi (methodological empiricism). Dengan Pendekatan ini telah banyak melahirkan hasil penelitian penting. Pemahaman pendekatan ini menjelaskan bahwa terjadi ketidakmerataan kesempatan pendidikan di duga merupakan hasil dari perselisihan antara kelas-kelas sosial berbeda kepentingan, mereka yang berada pada kelas sosial yang dianggap elit lebih suka mempertahankan status quo, sebaliknya mereka yang berada pada kelas-kelas populis terus berjuang lebih keras guna mendapatkan kesempatan dan peluang memperoleh pendidikan. (Toto Suharto, 2012.)

Pendekatan lainnya yang sering digunakan untuk merumuskan masalah kebijakan pendidikan, yaitu top-down, masalah pendidikan yang dianalisis adalah masalah pendidikan yang ditugaskan oleh atasan, misalnya Kementerian Pendidikan dan Kebudayaan memiliki mandate melaksanakan amanat undang-undang dan peraturan mengalokasikan anggaran pendidikan 20\% (amanat Undang-undang N omor 2 T ahun 2003 tentang Sistem Pendidikan $N$ asional), tentunya untuk menjalankan itu, dilakukan pendekatan pragmatis pada pihak terkait yakni pemerintah dan anggota legislatif. Analisis bisa merumuskan masalah penganggaran ini bila merasa bahwa analisis penganggaran ini memang diperlukan karena ada 
perbedaan pendapat tentang bagaimana cara mengatasi suatu masalah serta terdapat beberapa alternatif untuk memecahkan masalah penganggaran tersebut. (Sofian, 2021)

Lebih lanjut ada juga pendekatan kriteria sosial. D imana analis mencoba mencari fakta dan data untuk mengungkapkan ketidakpuasan publik sekaligus merumuskan masalah sosial yang mendesak dipecahkan. Perumusan masalah dalam analisis kebijakan pendidikan ini, bisa dilakukan dalam beberapa tahapan, antara lain: 1) fikirkan masalah pendidikan yang hendak diatasi, 2) tetapkan batasan dari masalah pendidikan, 3) kumpulkan fakta dan informasi dari masalah pendidikan yang akan diatasi, 4) rumuskan tujuan dan objektif yang relevan dengan masalah pendidikan yang akan diatasi, 5) identifikasi payung kebijakan (policy envelope) terhadap masalah pendidikan yang akan diatasi, 6) perhitungkan biaya dan manfaat dari masalah pendidikan yang akan diatasi, 7) tinjau kembali rumusan masalah pendidikan yang telah disusun.( Sofian, 2021)

Agar rumusan masalah dalam analisis kebijakan pendidikan lebih fokus, mendalam dan berkualitas, ada beberapa hal yang perlu dilakukan oleh analis, antara lain; 1) mempelajari masalah-masalah yang timbul dan masuk ke dalam agenda acara para pengambil kebijakan pemerintah, 2) mempelajari bagaimana khalayak merumuskan masalah-masalah pendidikan tersebut untuk pembuatan suatu tindakan, 3) mempelajari sikap apa yang diambil oleh badan legislatif atau lembaga lainnya atas kebijakan pendidikan, 4) mempelajari bagaimana para pemimpin merapatkan kebijakan pendidikan itu, 5) mempelajari bagaimana kebijakan pendidikan itu dievaluasi secara periodik, 6) mengidentifikasi payung hukum kebijakan pendidikan, 7) mengkalkulasikan biaya dan manfaat dari masalah yang hendak diatasi, 8) tinjau kembali rumusan masalah yang telah disusun. (Lindblom, CE, 1980)

\section{T ahapan Perumusan M asalah Kebijakan D an Perumusan Kebijakan Pendidikan}

Perumusan masalah kebijakan, menurut Weimer dan Vinning (2005) problem analysis consists of there major steps: 1) Understanding the problem; adalah memahami permasalahan dengan melakukan analisis permasalahan yang dihadapi melalui: menerima masalah (analisis gejala), memilih masalah (analisis kegagalan), memodelkan masalah (identifikasi variabel kebijakan), 2) choosing and explaining relevant policy goal and constraints, adalah melakukan pemilihan masalah, dan pada tahap, 3) choosing a solution method yaitu menggunakan metode yang tepat untuk mengatasi masalah. Terpenuhinya semua tahapan ini, para analisis bisa melakukan dengan mengumpulkan informasi, mengidentifikasi dan mengorganisasikan data yang relevan, teori dan fakta untuk menemukan masalah dan memprediksi akibat yang terjadi untuk tahap selanjutnya.(Lindblom, CE, 1980) 
Selanjutnya setelah perumusan masalah kebijakan selesai, dilanjutkan perumusan kebijakan. Lindblom (1980) dalam bukunya The Policy-M aking Process mengemukakan lima tahapan untuk mempelajari perumusan kebijakan pendidikan, antara lain 1) pelajari bagaimana masalah pendidikan itu timbul dan masuk ke dalam agenda acara para pembuat kebijakan pemerintah, 2) pelajari bagaimana khalayak merumuskan masalah pendidikan tersebut untuk pembuatan suatu tindakan, 3) pelajari sikap apa yang diambil oleh anggota legislatif atau lembaga lainnya atas kebijakan pendidikan itu, 4) pelajari bagaimana para pemimpin merapatkan kebijakan pendidikan itu 5) Pelajari bagaimana kebijakan pendidikan itu dievaluasi. Begitu juga dalam merumuskan suatu kebijakan pendidikan, ada beberapa tahapan yang bisa dilakukan, antara lain 1) penyusunan agenda pendidikan, 2) formulasi kebijakan pendidikan, 3) adopsi kebijakan pendidikan, 4) implementasi kebijakan pendidikan, dan 5) evaluasi kebijakan pendidikan.( Lindblom, CE, 1980)

\section{a. Aktor Dalam Perumusan Kebijakan Pendidikan}

Keberhasilan kebijakan pendidikan tidak lepas dari peran para aktor yang merumuskannya. Kajian terhadap aktor perumus kebijakan pendidikan merupakan hal yang menarik. Para aktor merupakan penentu isi kebijakan dan mewarnai dinamika tahapan dan proses perumusan kebijakan. Adapun Aktor dalam perumusan kebijakan pendidikan terdiri dari individu, kelompok, dan para pelaku pendidikan yang terlibat dalam berbagai kondisi sebagai satu kesatuan sistem kebijakan pendidikan.

Lester dan Stewart (2000) menyatakan bahwa para aktor perumus kebijakan dari pemerintah terdiri dari Birokrat Karier, Kantor Kepresidenan dan Kementerian, Lembaga Legislatif dan kelompok kepentingan yang berkaitan langsung dengan kebijakan secara spesifik, misalnya partai politik; organisasi penelitian; media komunikasi; serikat guru, asosisasi penyelenggara pendidikan tertentu, asosiasi peserta didik, asosiasi pimpinan perguruan tinggi, asosiasi orang tua peserta didik serta individu masyarakat. Mereka ini sering kali disebut sebagai peserta dari non-pemerintahan (non governmental participants). Peranannya dalam mensuplai informasi; memberikan tekanan ( pressures); serta untuk mempengaruhi.( M askuri, 2017)

Sub-sistem dalam perumusan kebijakan pendidikan terbentuk tatkala semua pihak antara lain pemimpin dan yang dipimpin, kelompok politik, masyarakat dan pihak swasta yang berpartisipasi, sehingga terjadi interaksi antara partisipan atau para aktor kebijakan saling mempengaruhi membentuk suatu parameter-parameter yang relatif stabil. Parameter itu dibatasi oleh sistem nilai ataupun faktor internal dan eksternal para aktor. Perubahan interaksi 
antar aktor juga disebabkan oleh perubahan sistem nilai tentunya akan berakibat pada perubahan sub-sistem kebijakan yang dihasilkan.

\section{b. M engadakan T ahapan Sosialisasi Kebijakan Pendidikan}

Ada beberapa tahapan-tahapan yang diperlukan diperhatikan dalam proses sosialisasi kebijakan tersebut ke masyarakat (public) termasuk di bidang pendidikan, yaitu: 1) tahap persiapan (preparatory stage), tahap meniru (play stage), dan 3) tahap tindakan (game stage).( M ead, 1962). D ari tahapan-tahapan sosialisasi kebijakan publik ini, kita bisa mengukur suatu keberhasilan suatu sosialisasi kebijakan, dilihat dari indikator pencapaian masing-masing tahapan sebagai berikut.

\section{c. T ahapan Persiapan (Preparetory Stage)}

Dalam tahap ini, setiap individu sebagai anggota masyarakat mempersiapkan diri dengan kebijakan yang akan ditetapkan, serta memahami dan membekali dengan nilai-nilai dan norma-norma yang menjadi pedoman dalam kebijakan tersebut, sehingga proses penerimaan produk kebijakan bisa dengan mulus karena sudah berkesesuaian dengan nilai dan norma yang ada dalam lingkungan tersebut.

\section{d. T ahapan M eniru (Play Stage)}

Pada tahap meniru ini mulai terbentuk kesadaran mengenai kebijakan baru. M asyarakat mulai menyadari tentang apa yang dilakukan oleh seorang pimpinan dan apa yang diharapkan dari kebijakan tersebut, atau masyarakat memiliki kemampuan untuk memposisikan diri pada kebijakan yang akan disahkan serta mulai terbentuk pada tahap ini. Kesadaran kolektif dari masyarakat mulai terbentuk sempurna sesuai dengan harapan dalam kebijakan.

\section{e. T ahap Siap Bertindak ( G ame Stage)}

Kemampuannya menempatkan diri pada posisi yang diharapkan mengalami peningkatan, sehingga menyebabkan adanya kemampuan beraktivitas secara bersama-sama dengan sempurna. Pada tahap ini masing-masing orang merasa puas, mereka saling memberi tahu koleganya, dan mulai memahami secara bertahap peraturan-peraturan yang berlaku. Pada kesempatan yang sama masyarakat mulai memahami bahwa ada aturanatau norma tertentu yang berlaku di lingkungannya ( awardness).

Strategi Sosialisasi Kebijakan Pendidikan Melalui Media Sosialisasi Kebijakan Pendidikan. Ada beberapa strategi dalam melaksanakan sosialisasi kebijakan pendidikan, sesuai dengan situasi dan kondisi unit kerja dan lingkungan masyarakat yang akan diberikan informasi sebagai berikut: 1) mendapatkan dukungan dari pimpinan tempat sosialisasi berlangsung, misalnya Mendikbud mensosialisasikan peraturan atau kebijakan pendidikan Dasar dan 
M enengah tahun 2018, semua pimpinan sudah memiliki satu semangat untuk merealisasikan kebijakan tersebut, mulai dari Menteri sampai pimpinan dibawahnya, 2) memberikan pemahaman kepada pejabat dan staf di lingkungan sosialisasi mengenai kebijakan, menjelaskan serta arti penting kebijakan pendidikan dalam mendorong efisiensi, efektifitas, peningkatan citra dan akuntabilitas kelembagaan, 3) menjelaskan kepada para aktor dan pegawai melalui seminar workshop, atau bimbingan teknis, 4) menyediakan berbagai media sosialisasi, seperti buku, poster, brosur, leaflet, $C D$, dan sebagainya, serta menyeberkan informasi tersebut media ke pihak-pihak yang akan melakukan sosialisasi, 5) membuat poster dan menempatkan pada papan-papan pengumuman dan menyediakan leaflet atau brosur pada tempat-tempat layanan terkait kebijakan yang ditetapkan, 6) menayangkan pada situs internet lembaga yang menetapkan kebijakan 7) menjadikan kebijakan sebagai salah satu tolok ukur bagi unit kerja lain dalam melakukan pengawasan, dan pembinaan serta menilai kepatuhan pelaksanaan kegiatan, 8) menjadikan penerapan kebijakan sebagai salah satu tolok ukur bagi pimpinan langsung dalam menilai kinerja bawahan.(D r. A rwildayanto et al., 2018)

Kebijakan pendidikan yang sudah dirumuskan dapat disosialisaikan dengan menggunakan berbagai media, baik berupa media komunikasi seperti poster, leaflet brosur, spanduk, dan baliho, maupun melalui media elektronik, seperti cakram optik ( compact disk atau DVD ), internet, radio dan televisi.

Dalam sosialisasi kebijakan pendidikan, poster dapat digunakan untuk berbagai macam keperluan, antara lain untuk mencapai tujuan: 1) memperkenalkan rangkaian kebijakan dan manfaatnya, 2) memperkenalkan prosedur terkait dengan kebijaka tersebut; 3) memberikan penawaran tertentu, seperti beasiswa serta prosedur atau persyaratan yang harus dipenuhi oleh pemohon; 4) membentuk sikap atau pandangan (propaganda) tertentu, seperti budaya kerja baru yang melekat pada kebijakan tersebut.( Dr. Arwildayanto et al., 2018)

Sesuai dinamika perkembang teknologi dibidang internet, maka sosialisasi kebijakan pendidikan yang paling efisien dan efektif serta ekonomis dilakukan melalui media sosial, misalnya facebook, twitter, instagram, whattshap group, line dan lain-lainnya. Bahkan secara massal bisa dilakukan melalui media TV, Koran, radio, Sedangkan melalui pertemuan tatap muka bisa di lakukan melalui Forum Diskusi Group (FGD), rapat sosialisasi, rapat pimpinan dan liannya yang dianggap forum sosialisasi kebijakan pendidikan.

\section{SIMPULAN}

Dari studi kepustakaan yang dilakukan maka didefenisikan bahwa kebijakan pendidikan merupakan suatu keputusan yang berhubungan dengan memecahkan 
permasalahan yang berhubungan dengan sistem pendidikan. M aka Perbincangan Sosialisasi Kebijakan Pendidikan Islam dalam pengembangan kebijakan pendidikan yang harus diperhatikan adalah harus mampu mengadakan pendekatan terhadap perumusan masalah kebijakan pendidikan, tahapan perumusan masalah kebijakan dan perumusan kebijakan pendidikan, aktor dalam perumusan kebijakan pendidikan serta harus mampu melakukan sosialisasi kebijakan pendidikan dan strategi sosialisasi kebijakan pendidikan melalui media sosialisasai kebijakan pendidikan. Setiap langkah dan tahapan harus dilaksanakan dengan optimal agar Perbincangan Sosialisasi Kebijakan Pendidikan Islam dapat diselesaikan serta dapat menciptakan kebijakan yang sesuai dengan harapan dan dapat di implementasikan dalam kebijakan pendidikan Islam.

\section{D aftar Pustaka}

Dr. Arwildayanto, M. P., Dr. Arifin Suking, M. P., \& Dr. Warni Tune Sumar, S.Pd., M. P. (2018). Analisis Kebijakan Pendidikan Kajian Teoritis, Eksploratif Dan Aplikatif. In Kebijakan Publik. (Vol. 53, Issue 9).

Lindblom, CE, T. P. (1980). M aking Process, Englewood Cliffs. Prentice-H all.

Maskuri. (2017). Kebijakan Pendidikan Sebagai Kebijakan Publik Dalam Sistem Politik Di Indonesia. Institut Agama Islam I brahimy Situbondo, 2(1), 81.

M ead, G. H . (1962). M ind, Self and Society, Chicago Charles W. M orris.

M uhibbin, M . . (2016). Program M itra W arga Sebagai Implementasi Kebijakan W ajib B elajar $12 \mathrm{~T}$ ahun di K ota Surabaya (1st ed.). Inspirasi manajemen pendidikan.

O ktavia, L. S., N urhidayati, \& Gistituati, N . (2021). Kebijakan Pendidikan: Kerangka, Proses dan Strategi. Jurnal Riset Tindakan Indonesia, 6( 1),95-99.

Perkotaan, P. M. (2009). Sosialisasi.htm(http:// www.P2Kp. org/about.asp) (p. diakses 31 O ktober 2009).

Rohman, M. (2015). PROBLEMATIKA KURIKULUM PENDIDIKAN ISLAM Mujibur Rohman 1.1-15.

Sofian, E. (2021). Pelatihan Analisis Kebijakan Publik (pp. 60-61). M AP-UGM .

Solichin, M . (2015). Implementasi Kebijakan Pendidikan Dan Peran Birokrasi. Religi: Jurnal Studi Islam, 6(2), 148-178.

Supeni, S. (2013). Sosialisasi Kebijakan Program Pendidikan Gratis dan Berkualitas pada Stakeholder dan Dewan Riset Daerah/Litbang Bappeda Kabupaten Wonogiri. Africa's Potential for the Ecological Intensification of Agriculture, 53(9), 1689-1699.

Tilaar, H .A.R. dan N ugroho, R. (2016). Kebijakan Pendidikan Pendidikan Pengantar Untuk 
M emenuhi Kebijakan Pendidikan Dan Kebijakan Pendidikan Sebagai Kebijakan Publik. Pustaka.

Toto, S. M. A. (n.d.). Pendidikan Berbasis M asyarakat; Relasi N egara dan M asyarakat dalam Pendidikan. LKIS Pelangi Aksara. 
